\section{SOI: 1.1 /TAS DOI: 10.15863 /TAS International Scientific Journal Theoretical \& Applied Science}

p-ISSN: 2308-4944 (print) e-ISSN: 2409-0085 (online)

Year: $2015 \quad$ Issue: 12 Volume: 32

Published: $30.12 .2015 \quad$ http://T-Science.org
Usmonjon Hayrullaevich Butayev

Scientific researcher The "National idea and Social philosophy" department Faculty of Social sciences The Mirzo Ulugbek National University of Uzbekistan naumenko06@mail.ru

SECTION 30. Philosophy.

\title{
THE PEACE AS A HUMAN BEING: THE EASTERN UNDERSTANDING
}

Abstract: This article considers the peace as an ontologically necessary condition (not in the narrow dichotomy of war and peace) without which it is not conceivable nor society as a right, nor normal society and its reproduction. To erect it into practice was a long of thousands of years.

Key words: peace, existence, human, mystic, East, West, logical analysis, a holistic view.

Language: Russian

Citation: Butayev UH (2015) THE PEACE AS A HUMAN BEING: THE EASTERN UNDERSTANDING. ISJ Theoretical \& Applied Science 12 (32): 38-40.

Soi: http://s-o-i.org/1.1/TAS-12-32-6 Doi: crossef http://dx.doi.org/10.15863/TAS.2015.12.32.6

\section{МИР КАК БЫТИЕ ЧЕЛОВЕКА: ВОСТОЧНОЕ ПОНИМАНИЕ}

Аннотация: Данная статья рассматривает мир как онтологически необходимое состояние (не в узком противопоставлении войны и мира), без которого немыслимы ни социум как порядок, ни нормальное общество и его воспроизводство. Возводить его на практике оказалось продолжительньм, длинною в несколько тысячелетий делом.

Ключевые слова: мир, бытие, человек, мистика, Восток, Запад, логический анализ, иелостное представление.

В свое время великий Иммануил Кант сказал: «Звездное небо связывает меня сквозь нескончаемые дали с мирами и системами миров в безграничном времени их вращения, их начала и продолжительности. На долю человеческого разума выпадала странная судьба: его осаждают вопросы, от которых он не может уклоняться, так как они навязаны ему его природой, но в то же время он не может ответить на них, так как они превосходит все его возможности» $[2,91]$.

Поистине, в мироздании заключено громадное количество проблем и вопросов, к решению или раскрытию которых человеческий интеллект не только не сможет подходить, но даже не сможет приблизиться. Дело в том, что есть такие извечные проблемы, которые не решатся никогда а для науки важно раскрыть их структуры для того, чтобы преодолеть их разрушительную силу. К такому относится и вопрос: что нужно делать, чтобы люди осознали состояние мира и спокойствия безальтернативно. Ибо, исторический и социальный опыт показал, что возможностей куда больше, чем трудностей. Хотя практика обременена многими нерешенностями, теория, мыслительная абстракция допускает возможность выхода из тупика. Последнее как известно связано с тем, что Homo sapiens став частью Вселенной не может не осознавать свою ответственность за своё местообитание и стремился всеми возможными путями к состоянию, которое бы выступало условием продолжения жизни. Позднее выяснилось: к пониманию его люди, народы приходят не одновременно и мыслят об этом различными категориями. В процесс вмешиваются так называемые социокультурные детерминанты. В последствие обозначились две - западная и восточная - версии жизнепонимания т.е. бытия человека. Итак налицо усложнение самоочевидного.

Истоки разных подходов к проблеме, с большей долей вероятности, связаны с восприятием «соприсутствия» Человека и Вселенной. В одной части планеты, точнее на Западе, традиционно в связке «Человек и Природа» усматривали неискоренимое онтологическое противоречие. Чрезмерное возвеличивание мощи разума логически приводило сознание к тому, что разум абсолютен, что превосходство последнего над окружающим 
не подлежит сомнению, предпослано. Усмотрев во Вселенной извечный хаос, наделили человеческий разум демиургическими способностями устанавливать единственно возможный порядок. В сознании людей в западной части планеты под воздействием отчасти религиозных, отчасти светских учений закреплялось мнение: человеческий разум самочинно, без согласия с природой и в противовес ей способен навести порядок. Практически объявлялась война против природы следовательно фундаментальной опоре гармонии бытия. Состояние природной гармонии, спокойствия бытия как начала начал было нарушено, что и завладело и сознанием, и мышлением, и поведением.

К счастью в других ареалах Земли, зарождалось принципиально другое, противоположное этому, начало нашедшее свое выражение в религиозно-философских, общественных идеях, литературе (даосизм, конфуцианство, буддизм, индуизм и ханафитский ислам). Интеллектуальный мейнстрим определялся тем, что, во-первых, бытие необходимо целостно в разнообразии, во-вторых, то, что мироздание держится исключительно благодаря мирному импульсу, т.е. «закону всемирного тяготения». Во всех восточных учениях - от пантеизма до конфуцианства Вселенная заключает в себе мирное начало, нацеленное на утверждение жизни как непреходящей ценности. Главный импульс всего живого, по восточным доктринам, в наличии некой нравственной обязанности индивида сосуществовать с окружающей его природой [3, 288]. В этой связи крупнейший буддийский философ Дайсаку Икеда высказывал следующую мысль: «По буддийскому мировоззрению, вся Вселенная, в том числе и Земля, по существу, является носителем жизни и постоянно сохраняя в себе жизнь в состоянии «ку», т.е. в «состоянии бытия», погруженного в небытие. Представляется, что Вселенная сама является «морем жизни», обладающей потенциальной силой рождения жизни» [4, 302]. Мысль японского мыслителя намекает на то, что Вселенная и жизнь взаимообусловлены, направлены на создание всех необходимых условий для творческой жизни. Как бы продолжая Дайсаку Икеда российский философ Т.Григорьева, пишет: «Для того, чтобы ответить на этот вопрос, следует, видимо, принять во внимание характер “как бы двойного бытия", чтобы не принимать видимое за сущее. Всё имеет две природы, неявлённую и явлённую, вечную и непреходящую, небесную и земную. В первой, небесной природе, все вещи едины, во второй, земной, различны и преходящи» $[5,135]$.
Сходный целостный подход к мирозданию и к человеческой жизни многократно встречаем в философиях других народов Востока, за весь тысячелетний период её существования и развития. «Образно-целостное видение мира является заветом древневосточной культуры, её важным знаковым свойством. Мистическое единство природных стихий под верховенством небесных светил выступает как образ социального порядка» $[6,47]$. Говоря о специфике восточного философствования, казахстанские философы А.Нысанбаев, Н.Сейитахметова пишут, что в тюрских мировосприятческих традициях неизменно преобладала идея о том, что «индивидуальность человека определяется не противопоставлением его обществу и природе, что гармоничное единство Я-Ты, Я-Другой, где возможно открытие простора для другой личности, ориентировано на понимание другого человека, «другой культура» [7, 47].

На огромных просторах того, что мы называем «Восток» - от Тихого и Индийского океанов до Босфора, как видно из источников, сложилась уникальная философская культура с благоговейным отношением к гармонии, стабильности, что по сей день во многом определяет особое отношение индивида, субъекта к сущности человека. Человек в восточной философии един с окружением, что в свою очередь, представляется им не неким противостоящим, а «событийствующим». Такое понимание бытия особенно актуально в наше время, когда по поводу и без повода проводится разделительная линия между людьми, народами, культурами, цивилизациями, государствами, делая мир ещё более расколотым. В такой ситуации больше всех страдает мир (гармония) как состояние души, благодаря чему человеческий род возвысился до того, чем является мироздание. Ибо мир, стабильность зиждется лишь на взаимодействии и на взаимном диалоге. В наше крайне неспокойное время очень важно, чтобы различие, разность в мировосприятии народов стало полем для диалога, культурного обмена. Ибо, как говорил один из великих людей война начинается не из-за различий действ, а в мыслях людей, охватывая затем все другие области. В свое время крупнейший японский философ Т.Судзуки в связи с этим скажет: «Дзен - мистик, по-другому быть не может, ибо дзен основа восточной культуры. Именно этот мистицизм мешает Западу понимать восточное сознание, так как основная черта западного сознания заключается в логике и логическом анализе. Для восточного мистицизма подобная логика неприемлема» [8].

Спору нет, мистика логическому анализу не поддаётся, у нее другой конструкт, это не 
приводит к противопоставлению с логикой западной традиции. Ибо и у того, и у другого лишь разные способы познания бытия. Это говорит в пользу того, что в изучении предназначения человека как разумного существа все еще не хватает альтернативных подходов, что в мышлении и сознании человека как субъекта культурно-исторического процесса продолжает господствовать стародавняя формула «человек человеку - волк». По сей день выплёскиваются наружу догматы о «предзаданной агрессивности» людской породы, но к счастью, последние отвергаются практически всеми социальнофилософскими традициями, в особенности восточного ареала $[9,10]$.

Человечество в целом осознало: в современном крайне неспокойном мире стабильности, безопасности «родного очага», нет альтернативы. Этот тренд становится господствующим и во внешней политике стран Востока. Для лучшей иллюстрации сошлёмся на недавнюю беседу главного редактора узбекистанского журнала «Жахон адабиёти» («Мировая литература») с Чрезвычайным и Полномочным Послом Исламской Республики Иран в Узбекистане господином Али Мардани Фардом «Создаётся впечатление, что в конце XX века мир возвращается к эпохе крестовых походов. Трагические последствия Второй мировой войны не уступают «крестовому походу». Главной причиной всего этого является доминирование логики войны над логикой диалога цивилизаций. Известно, что войны сначала начинаются в сферы идеологии внутри человеческого мышления. Если так, прежде чем начинать рыть окопы в поле битв, нужно возводить оборонительные стены в нашем мышлении. В истории, в силу того, что нации, народы, по понятным причинам знали друг о друге крайне мало, пышно расцвела планетарная болезнь - болезнь недоверия между народами, что в свою очередь, подготавливало почву для эскалации военных действий. Мир, установленный по замыслу «избранных» народов не может быть долговечным. Мир, основанный на ценностях единства и взаимодействия - это уже вечный мир» $[10,62]$.

Отсюда вытекает вывод: а) мир - основа основ вечности людского рода; б) это тот исток, от которого брала свое начало Вселенная; в) это непреходящая ценность, на которой держатся история, общество и человек. Парадоксально, что человеческая мысль по многим субъективным причинам, по сей день преимущественно ориентируется не на объединяющие, а, напротив, разъединяющие факторы. XXI век представляется нам веком, который настоятельно требует кардинального изменения координат понимания и объяснения бытия, поиска новых выходов на новые горизонты созидания во имя утверждения мира на Земле. Негоже, говорить о мире лишь во время войны и конфликтов: он требует к себе нового подхода, в основе которого лежала бы идея о без альтернативности мирной жизни каждого и всех.

\section{References:}

1. Karimov IA (2008) Juksak ma\#navijat engilmas kuch. T.: Uzbekiston, 2008.

2. Gor'kavyj N (2015) - Skazka s kosmicheskom puteshestvennike Immanuile Kante, kotorogo vse schitali filosofom-domosedom. // Nauka i zhizn', №4, 2015. pp.91.

3. (2007) Izberi zhizn'. Dialog Arnol'da Tojnbi i Dajsaku Ikeda. Moscow: 2007, pp. 288.

4. (2007) Izberi zhizn'. Dialog Arnol'da Tojnbi i Dajsaku Ikeda. Moscow: 2007, pp.302.

5. Grigor'eva TP (2015) Buddizm i sovremennaja mysl' // Voprosy filosofii, №6, 2015. - pp.135.

6. Jan Vil'jam (2005) Siverc van Rejzema (A.I.Argumentskij-Dolgorukij Filosofija planetarizma). Moscow: 2005. pp.47.
7. Nysanbaev A, Sejitahmetova N (2013) Filosofija vozvrashhenija: opyt kazahstanskoj filosofii // Voprosy fillosofii, 2013, №7, pp.47.

8. (2015) Mistika v ljubom svoem tolkovanii ukazyvaet na stremlenie cheloveka k slijaniju s okruzheniem, kak blizkim, tak i bezgranichno otdalennym, t. e. Absoljutom.

9. Bljumenkranc MA (2012) Kuda letish', trojanskij kon', i gde opustish' ty kopyta // Voprosy filosofii, №4, 2012, pp. 10.

10. Jeron Islom (2015) Respublikasining Yzbekistondagi Favkulotda va Muhtor Jelchisi Ali Mardoni Fard bilan suxbat. // Zhaxon adabijoti, 2015. 2-son. pp.162. 